and neighbouring parts of East Greenland. Meddr Grønland Geosci. 15, 24 pp.

Kalsbeek, F. 1989: GGU's expedition in the Disko Bugt area, 1988. Rapp. Grønlands geol. Unders. 145 (this volume).

Longman, I. M. 1959: Formulas for computing the tidal accelerations due to the moon and sun. J. Geophys. Res. 64, 2351-2355.

Morelli, C. 1974: The international gravity standardization net 1971 (IGSN 1). Spec. Publ. int. Ass. Geodesy 4, 190 pp.

Sjøberg, L. 1982: Singular versus regular adjustment of gravity networks for various observation strategies. Rep. Dept. Geodesy, Inst. Geophys., Univ. Uppsala 15, 29 pp.
Thorning, L. 1982: Processing and interpretation of aeromagnetic data in the Geological Survey of Greenland. Rapp. Grønlands geol Unders. 114, 42 pp.

Thorning, L. 1988: Reconnaissance aeromagnetic survey east of Disko Bugt, central West Greenland. Rapp. Grønlands geol. Unders. 140, 26-27.

L. T., Grønlands Geologiske Undersøgelse, Oster Voldgade 10 DK-1350 København K, Danmark.

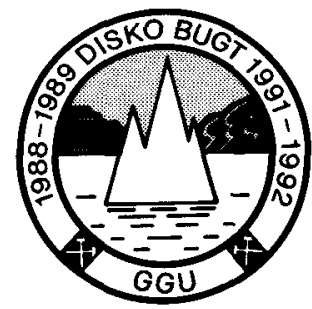

Middle Proterozoic ultramafic lamprophyre dykes in the Archaean of the Atâ area, central West Greenland

\author{
Mogens Marker and Christian Knudsen
}

During the mapping of gneisses and supracrustal rocks around Eqe in the eastern part of the Atâ area in 1988 a series of ultramafic dykes of lamprophyric affinity were discovered by the authors. The dykes are conspicuous in the field because of their lithology, with often high contents of carbonate, and the occurrence of brownish phlogopite phenocrysts. Their ductile type of deformation and aggressive alteration of the wall-rock are distinctive. The purpose of this paper is to give a preliminary account of the mode of occurrence and lithology of the dykes based on the mapping results and a provisional inspection of a dozen thin sections. Their possible age is discussed on the basis of their spatial relation to a large NNW-SSE trending dolerite dyke dated at $1645 \pm 35 \mathrm{Ma}$ by Kalsbeek \& Taylor (1986).

\section{Field relations}

The area around Eqe consists of migmatitic gneisses and more or less foliated granitoid rocks of Archaean age (fig. 1). To the east along the Inland Ice these give way to low to medium grade supracrustal rocks which are supposed also to be of Archaean age (Knudsen et al., 1988; Kalsbeek, 1989). The ultramafic lamprophyre dykes are common throughout the Eqe area where they follow pronounced lineaments (fig. 1). Most dykes are sub-vertical and trend $\mathrm{E}-\mathrm{W}$. There is a large concentration of E-W dykes in a swarm parallel to the coast in the northern part of the area and another, less pronounced, concentration in a wider zone through the central part of the area. In addition, ultramafic lamprophyre dykes occur locally following NW-SE to NNW-SSE lineaments (fig. 1), but they are far more rare. The NW-SE dykes were often observed to be strongly magnetic in the field, but also the E-W dykes may show a more or less pronounced magnetism.

With a few exceptions, which will be described later, all ultramafic lamprophyre dykes are found only to cut the Archaean basement gneisses or amphibolite layers within them. At one locality, in the central part of the area shown in fig. 1, a dyke has been observed to continue from the gneisses and amphibolites into the supracrustal rocks. Elsewhere the dykes appear to stop at the boundary to the latter. There is no obvious reason for this, since the ultramafic lamprophyre dykes seem to be much younger than the supracrustal rocks and the E-W lineaments associated with the dykes continue into the supracrustal rocks from the gneisses. A possible explanation for this discrepancy could be that the thin ultramafic lamprophyre dykes are difficult to detect in the mostly darker and more crumbled supracrustal rocks, which additionally often have a more extensive Quaternary cover.

Individual dykes commonly range from a few centimetres to 1-2 $\mathrm{m}$ in thickness, but some dykes may be as much as 4-5 m thick. The dykes have a straight course and cut right through earlier structures within the gneisses. Nevertheless, they often show strong internal deformation including tight, ductile, small-scale folding and shearing (fig. 2). The country rock immediately 


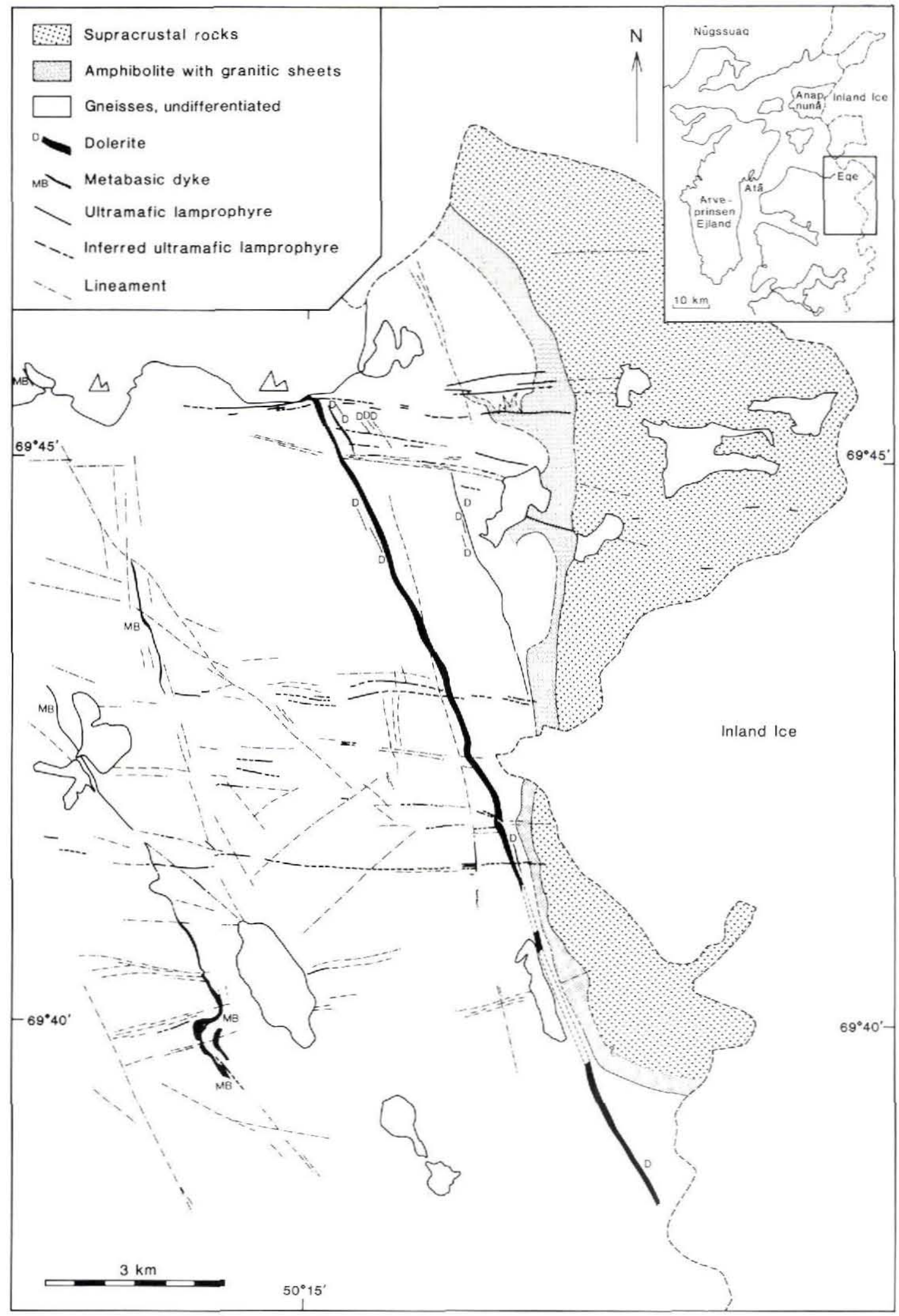

Fig. 1. Map of dykes and lineaments in the Eqe area. The ultramafic lamprophyre dykes may be more continuous than shown because a supposed continuation beneath Quaternary cover is not indicated. The metabasic dykes or sheets are older than the other dykes. 
Fig. 2. Ultramafic lamprophyre dyke showing characteristic zoned lithology with contact (dashed line) to wall rock (gneiss sheeted amphibolite) to the left. Note the deformed and smallfolded structure of the dyke. From a c. $3 \mathrm{~m}$ thick dyke in the northern part of the Eqe area.

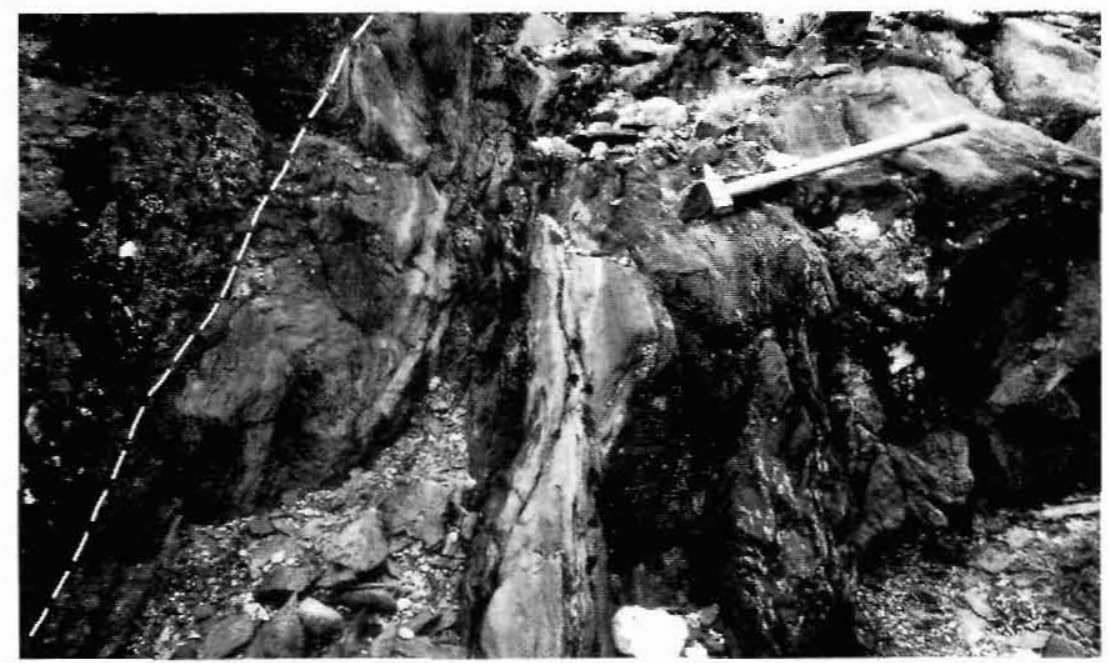

surrounding the dykes is often more or less bleached and oxidised with a pale reddish tinge. Often the contact between a dyke and the country rock is folded with sub-horizontal fold axes and axial planes (fig. 3).

In spite of their limited thickness, the ultramafic lamprophyre dykes are characteristically heterogeneous with a rapid change in lithology across the dyke (fig. 2). The dykes range from grey carbonate-rich types to black amphibole-rich types and almost monomineralic biotite rocks. Grey brownish weathered carbonate-rich rocks with lustrous pale brownish phenocrysts of phlo-

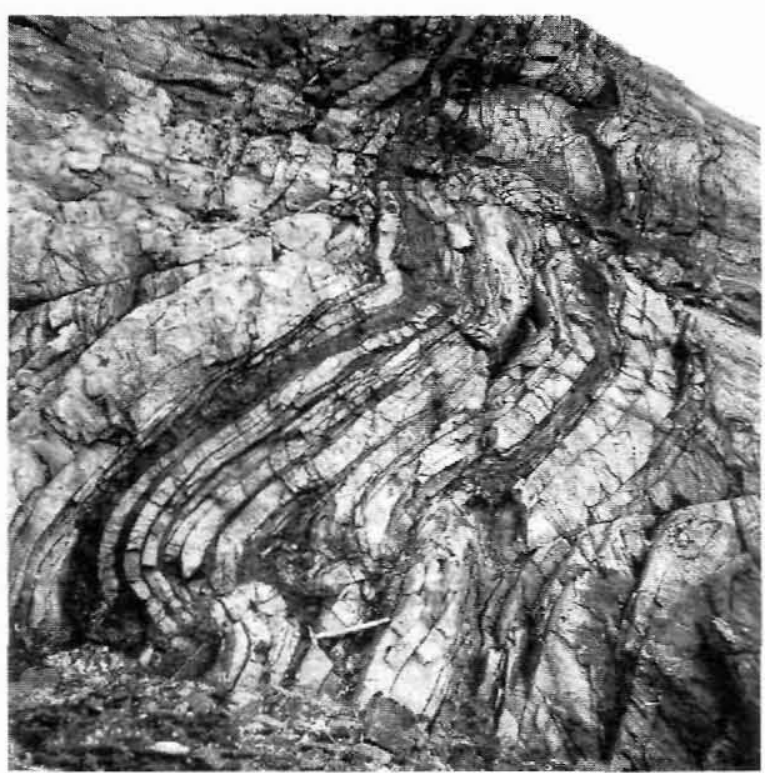

Fig. 3. Folded swarm of closely spaced ultramafic lamprophyre dykelets in gneiss. The gneiss foliation dips moderately steep to the right discordant to the dykelets. From a set of NNW-SSE trending dykes in the central part of the Eqe area. gopite tend to dominate the centre of most dykes, while strongly deformed amphibole- and biotite-rich rocks tend to dominate at their margins. Within a few centimetres from the contact to the dykes, the country rock is always strongly altered, with more or less recrystallised original feldspar grains in a matrix rich in biotite and devoid of quartz. This country rock metasomatic alteration, which emphasizes the alkaline nature of the dykes, is also observed on joint surfaces in several E-W lineaments where dykes have not been found. This suggests that ultramafic lamprophyre dykes may be even more widespread than it appears from the map (fig. 1). At several localities dykes have been observed to contain inclusions of country rocks which are similarly strongly altered.

\section{Petrography of the dykes}

From field observations and a preliminary study of thin sections three rock types have been distinguished.

Group A: Grey homogeneous carbonate-rich rocks with phlogopite phenocrysts. This common rock type is mainly finegrained with scattered $2-7 \mathrm{~mm}$ large zoned phenocrysts of phlogopite and up to $4-5 \mathrm{~mm}$ long white ellipsoidal globules which consist of an aggregate of carbonate grains. Carbonate makes up $20-50 \%$ and colourless amphibole $10-50 \%$ of the rock. The rock is always rich in opaque minerals and is clearly magnetic. Sphene(?) occurs as a sparse accessory mineral associated with the opaque minerals. Two samples with the lowest contents of amphibole contain fine-grained, interweaving aggregates of serpentine(?) and/or chlorite(?), which in one sample make up almost half of the rock. The phlogopite phenocrysts are beautifully zoned with an almost colourless outer zone and darker centres which are successively more densely clouded due to tiny dark inclusions. In one sample a sub- 
ordinate amount of unclouded phlogopite occurs in the matrix also.

Group B: Light grey, foliated carbonate-rich rocks with lenticular texture. This medium-grained rock type shows a pronounced wavy lenticular texture with $8 \mathrm{~mm}$ long lenticles composed of carbonate surrounded by screens dominated by pale brownish phlogopitic mica \pm amphibole. Carbonate makes up $50-70 \%$ of the rock, phlogopitic mica about $25 \%$. In one sample, which contains small inclusions of country rock, a strongly pleochroitic blue amphibole makes up about $25 \%$ of the rock. One magnetic sample contains c. 5\% opaque minerals. Another sample contains $2-3 \%$ sphene. Apatite is an accessory mineral.

Group C: Dark grey to black foliated amphibole-biotite rocks. These rather varied rocks occur mostly along the margins of the dykes. They are characterised by low contents of carbonate and high contents of rather pale green amphibole and brown to olive biotite. One type is a fine- to medium-grained, homogeneous dark grey rock composed of $50-60 \%$ amphibole, $30 \%$ biotite, $2-5 \%$ carbonate, $5 \%$ sphene and $2 \%$ opaque minerals which is texturally reminiscent of the group A rocks. Another homogeneous type is a medium-grained rock which is black with white specks of carbonate aggregates (20\%). Biotite makes up $40 \%$, amphibole $30 \%$, sphene $7 \%$ and opaque $2 \%$. A common type is a foliated, black, medium-grained rock composed of $75 \%$ amphibole and $25 \%$ biotite with carbonate and opaque minerals in accessory amounts. This type grades into almost pure foliated biotitic rocks.

Rocks from the NW-SE trending ultramafic lamprophyre dykes in the western part of the Eqe area have not yet been studied in thin section. Tentatively, these black, fine-grained, highly magnetic rocks, which seem to have a low content of carbonate, are incorporated within group $\mathrm{C}$.

The rocks from the scattered dykes found within the supracrustal rock sequence in the eastern part of the area (fig. 1) are grey, mainly fine-grained, homogeneous rocks with a high content of carbonate. Superficially they resemble the rocks of group A above. However, there are important differences which necessitate a separate treatment. Firstly, these dykes do not seem to have any significant lithological zoning across them. Secondly, wall rock alteration comparable to that along dykes injected into the gneisses has not been observed. Thirdly, the two samples studied in thin section both contain quartz, one as much as $10 \%$. In spite of similarity in hand specimens the one is composed of $80 \%$ colourless amphibole and $15 \%$ carbonate, with opaque minerals, sphene(?) and quartz as accessory minerals, and the other of $75 \%$ carbonate, $10 \%$ light yellowish brown phlogopitic biotite(?) and $10 \%$ quartz, with accessory opaque minerals. The quartz is fine-grained and evenly distributed in the rocks. In the sample richest in
Table 1. Microprobe analyses of blue amphibole

\begin{tabular}{lrrrr}
\hline & 1 & \multicolumn{1}{c}{2} & \multicolumn{1}{c}{3} & average \\
\hline $\mathrm{SiO}_{2}$ & 56.14 & 55.84 & 56.13 & 56.04 \\
$\mathrm{TiO}_{2}$ & 0.21 & 0.22 & 0.27 & 0.23 \\
$\mathrm{Al}_{2} \mathrm{O}_{3}$ & 1.45 & 1.17 & 1.34 & 1.32 \\
$\mathrm{FeO}$ & 16.80 & 16.72 & 17.03 & 16.85 \\
$\mathrm{MnO}$ & 0.04 & 0.08 & 0.12 & 0.08 \\
$\mathrm{MgO}$ & 14.08 & 13.80 & 14.11 & 14.00 \\
$\mathrm{CaO}$ & 2.99 & 2.63 & 2.65 & 2.75 \\
$\mathrm{Na}_{2} \mathrm{O}$ & 6.38 & 6.48 & 6.72 & 6.53 \\
$\mathrm{~K}_{2} \mathrm{O}$ & 0.72 & 0.83 & 0.89 & 0.81 \\
$\mathrm{Cr}_{2} \mathrm{O}_{3}$ & 0.10 & 0.05 & 0.00 & 0.05 \\
$\mathrm{NiO}$ & 0.00 & 0.00 & 0.00 & 0.00 \\
$\mathrm{Total}$ & 98.92 & 97.81 & 99.26 & 98.66 \\
\hline
\end{tabular}

Analyses carried out at the Institute for Mineralogy, University of Copenhagen. (1-3) Different blue amphibole crystals in sample GGU 362463.

quartz, a 2-3 mm large aggregate of larger quartz grains occurs as well. If quartz is diagnostic for the isolated dykes within the supracrustal rock sequence it may be questioned whether these rocks form part of any of the above-mentioned rock groups of the ultramafic lamprophyre dykes. Their lack of lithological zoning and different contact relations with country rock could reinforce this suspicion and indicate that they make up a separate group of dykes.

The composition of the blue amphibole has been determined by microprobe analysis carried out by $\mathrm{J}$. Rønsbo (Table 1). The composition corresponds to a magnesioriebeckite (calculated on the basis of 13 cations in $Y+Z$ positions leading to $\mathrm{Na}+\mathrm{K}=0.33$ in the A position). The blue amphibole occurs abundantly in one carbonate-rich sample of group B, which in addition contains altered inclusions of country rock, and in two samples of metasomatically altered country rock. This suggests that the blue Na amphibole formed by reaction of the carbonate-rich magma with the country rock.

\section{Discussion of age relations}

The age of the ultramafic lamprophyre dykes from the Eqe area may be inferred from their intrusive relations to a large NNW-SSE trending dolerite dyke which cuts through the area (fig. 1). This dyke, which is at least $400 \mathrm{~km}$ long, has been dated at $1645 \pm 35$ Ma by Kalsbeek \& Taylor (1986). The dyke consists of olivinerich dolerite and is chemically classified as subalkaline (Kalsbeek \& Taylor, 1986). Several thin olivine dolerite 
Fig. 4. Spatial relations between ultramafic lamprophyre dykes and dolerite dykes.

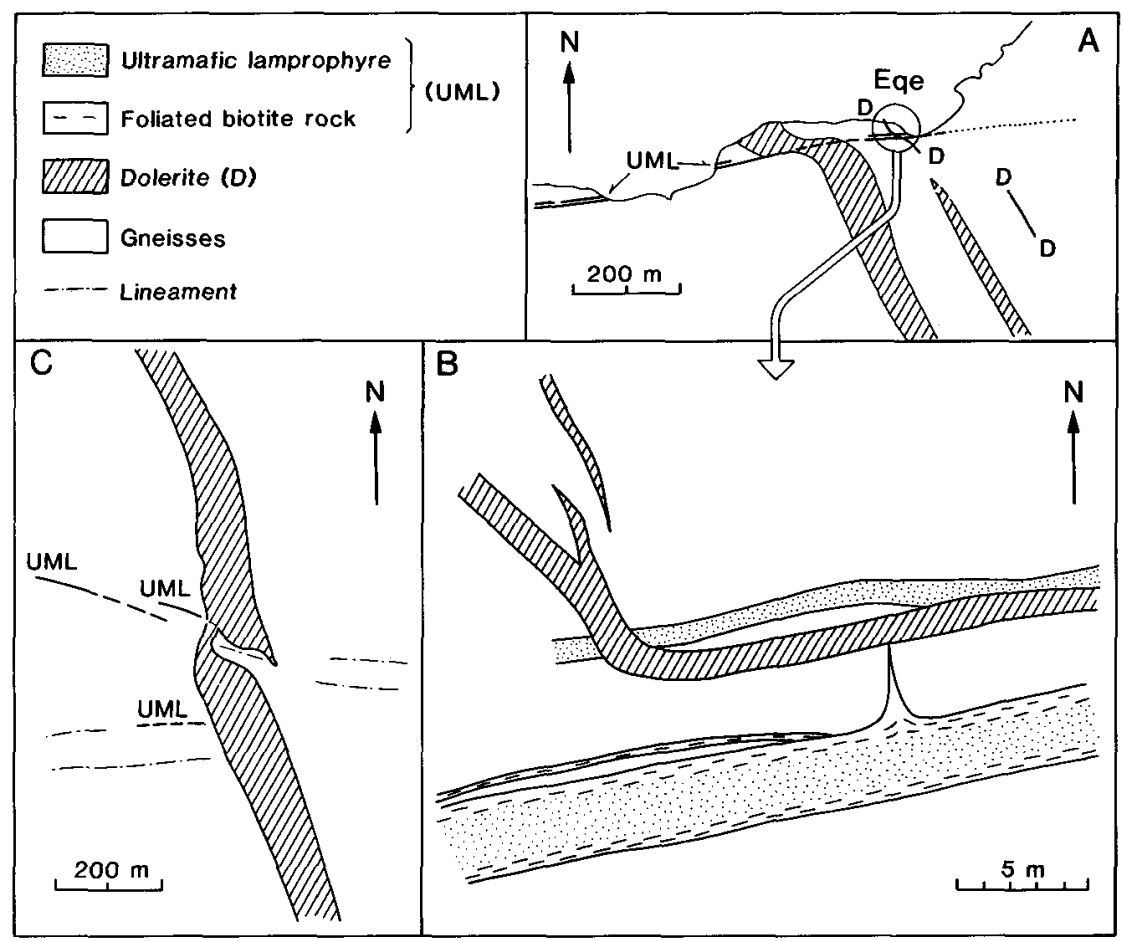

dykes occur parallel to the large dyke and are therefore suggested to be of the same age.

At the coast in the northern part of the Eqe area one of these thin satellite dykes is seen to cut an E-W ultramafic lamprophyre dyke (fig. 4A,B). The general NNW-SSE trend of the dolerite dyke is deflected into parallelism with the ultramafic lamprophyre dyke in the zone where this is crossed, so that the dolerite achieves a spectacular sinistral bend. Further west, a similar sinistral bend with an 'offset' of $c .100 \mathrm{~m}$ is seen in the large dolerite dyke where it is crossed by the same E-W zone of ultramafic lamprophyre dykes (fig. 4A). However, the dolerite dyke is here clearly cut by the ultramafic lamprophyre dyke which has even altered the dolerite metasomatically along the contact.

Other evidence for the intrusive relations between the two kinds of dykes comes from the central part of the Eqe area (fig. 4C). Here the large dolerite dyke shows a peculiar necking phenomenon where it is crossed by an E-W trending zone with ultramafic lamprophyre dykes. These dykes do not cut the dolerite dyke itself. The dolerite dyke shows intrusive contacts and chilled margins everywhere along the necking structure, which accordingly must be a primary intrusive feature. But it appears that the intrusion pattern of the dolerite dyke has been partly controlled by the relatively ductile crossing zone of ultramafic lamprophyre dykes.
Taken together, the field relations show that the dolerite dyke both cuts and is cut by the ultramafic lamprophyre dykes just as its intrusive pattern is influenced by the emplacement of the latter. It also appears that narrow zones immediately surrounding some of the ultramafic lamprophyre dykes have reacted rather ductile during their emplacement. It is logical to assume that all the E-W trending ultramafic lamprophyre dykes belong to the same swarm, and if this is true it may be concluded that the intrusion of dolerite and ultramafic lamprophyre dykes was more or less contemporaneous, i.e. around 1635 Ma old.

\section{Conclusion}

The ultramafic lamprophyre dykes form a conspicuous part of the geology of the Eqe area. The rock compositions and field relations described above strongly suggest a classification of the dykes as ultramafic lamprophyres. Their high carbonate content, the widespread occurrence of zoned phlogopite phenocrysts of probable igneous origin and high Ti content as witnessed from the occurrence of (secondary? or metamorphic?) sphene all point to this conclusion. Their alkaline affinity is indicated by the metasomatic alteration of the country rock and by the occurrence of blue pleochroitic $\mathrm{Na}$ amphibole in some samples. The very high carbonate content in many dykes could suggest 
that they sometimes grade into carbonatites which is normal for ultramafic lamprophyres (Rock, 1987). The zoned internal structure indicates that the dykes were either injected by multiple intrusion or differentiated by secondary processes such as reaction with country rock or by metamorphic differentiation. The mineral assemblages are probably essentially metamorphic as is also suggested by their characteristic internal deformation.

The ultramafic lamprophyre dykes are possibly also widespread in other parts of the district where similar dykes have been observed in the yet sparsely mapped area west of Eqe. Dykes of lamprophyric affinity are known both from South-West Greenland (Hansen, 1980), from the Holsteinsborg area in central West Greenland (Larsen, 1980; Larsen et al., 1983) and from the Umanak district (Larsen \& Møller, 1968). While the lamprophyric dykes in South-West Greenland are of Mesozoic age, the dykes from central West Greenland range in ages from Eocambrian to Late Archaean. However, no dykes are reported to have ages around the $c .1635 \mathrm{Ma}$ as deduced above.

In an economic-geological context it is interesting that the ultramafic lamprophyre dykes of the Eqe area follow the same general trends as gold-mineralized shear or breccia zones in the western part of the supracrustal rock sequence (Knudsen et al., 1988). A similar feature occurs in the Norseman - Wiluna Belt of the Yilgarn Block in the Precambrian of Western Australia where there is a spatial and chronological coincidence between lamprophyre dykes and epigenetic gold mineralization (Rock \& Groves, 1988).

Acknowledgements. Jørn Rønsbo is thanked for carrying out microprobe analyses at short notice and for having calculated the composition of the blue amphibole. Special thanks go to Lotte Melchior Larsen for valuable suggestions which im- proved the manuscript. The field work was partly supported by Carlsbergfondet (grant nr. 87050120 to C. K.).

\section{References}

Hansen, K. 1980: Lamprophyres and carbonatitic lamprophyres related to rifting in the Labrador Sea. Lithos 13, 145-152.

Kalsbeek, F. 1989: GGU's expedition in the Disko Bugt area, 1988. Rapp. Grønlands geol. Unders. 145 (this volume).

Kalsbeek, F. \& Taylor, P. N. 1986: Chemical and isotopic homogeneity of a $400 \mathrm{~km}$ long basic dyke in central West Greenland. Contrib. Mineral. Petrol. 93, 439-448.

Knudsen, C., Appel, P. W. U., Hageskov, B. \& Skjernaa, L. 1988: Geological reconnaissance in the Precambrian basement of the Atâ area, central West Greenland. Rapp. Grønlands geol. Unders. 140, 9-17.

Larsen, L. M. 1980: Lamprophyric and kimberlitic dykes associated with the Sarfartôq carbonatite complex, southern West Greenland. Rapp. Grønlands geol. Unders. 100, 65-69.

Larsen, L. M., Rex, D. C. \& Secher, K. 1983: The age of carbonatites, kimberlites and lamprophyres from southern West Greenland: recurrent alkaline magmatism during 2500 million years. Lithos 16, 215-221.

Larsen, O. \& Møller, J. 1968: K/Ar age determinations from western Greenland I. Reconnaissance programme. Rapp. Grønlands geol. Unders. 15, 82-86.

Rock, N. M. S. 1987: The nature and origin of lamprophyres: an overview. In Fitton, J. G. \& Upton, B. G. J. (edit.) Alkaline igneous rocks. Spec. Publ. geol. Soc. Lond. 30, 191-226.

Rock, N. M. S. \& Groves, D. I. 1988: Do lamprophyres carry gold as well as diamonds? Nature 332, 253-255.
M. M.,

Institut for Almen Geologi, $\emptyset$ ster Voldgade 10,

DK-1350 Kobenhavn $K$,

Danmark.
C. $K$., A/S Faxe Kalkbrud, Frederiksholms Kanal 16, DK-1017 Kobenhavn K,

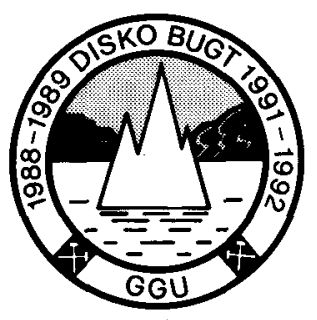

A reinvestigation of the major fault in Sarqaqdalen was undertaken in 1988 in response to a renewed interest in the style and timing of the whole fault system that marks the easterly limit of Cretaceous sediments in central West Greenland. This interest stems in turn from the reinterpretation of seismic lines from the 1970 s that has recently been initiated in GGU (Chalmers, $1988 ; 1989)$. Dating of seismic sequences is influenced greatly by what can be learnt from the nearest onshore outcrops, for example proven unconformities in onshore sequences, and demonstrable relationships between sedimentation and fault movements. 